\title{
A multi-layered view of chemical and biochemical engineering
}

Gani, Rafiqul; Badyga, Jerzy; Biscans, Béatrice; Brunazzi, Elisabetta; Charpentier, Jean-Claude; Drioli, Enrico; Feise, Hermann; Furlong, Andrew; Geem, Kevin M Van; Hemptinne, Jean-Charles de Total number of authors:

22

Published in:

Chemical Engineering Research and Design

Link to article, DOI:

10.1016/j.cherd.2020.01.008

Publication date:

2020

Document Version

Peer reviewed version

Link back to DTU Orbit

Citation (APA):

Gani, R., Badyga, J., Biscans, B., Brunazzi, E., Charpentier, J-C., Drioli, E., Feise, H., Furlong, A., Geem, K. M. V., Hemptinne, J-C. D., Kate, A. J. B. T., Kontogeorgis, G. M., Manenti, F., Marin, G. B., Mansouri, S. S., Piccione, P. M., Povoa, A., Rodrigo, M. A., Sarup, B., ... Woodley, J. M. (2020). A multi-layered view of chemical and biochemical engineering. Chemical Engineering Research and Design, 155, 133-145.

https://doi.org/10.1016/j.cherd.2020.01.008

\section{General rights}

Copyright and moral rights for the publications made accessible in the public portal are retained by the authors and/or other copyright owners and it is a condition of accessing publications that users recognise and abide by the legal requirements associated with these rights.

- Users may download and print one copy of any publication from the public portal for the purpose of private study or research.

- You may not further distribute the material or use it for any profit-making activity or commercial gain

- You may freely distribute the URL identifying the publication in the public portal 


\section{Journal Pre-proof}

A multi-layered view of chemical and biochemical engineering

Rafiqul Gani, Jerzy Bałdyga, Béatrice Biscans, Elisabetta Brunazzi, Jean-Claude Charpentier, Enrico Drioli, Hermann Feise, Andrew Furlong, Kevin M Van Geem, Jean-Charles de Hemptinne, Antoon

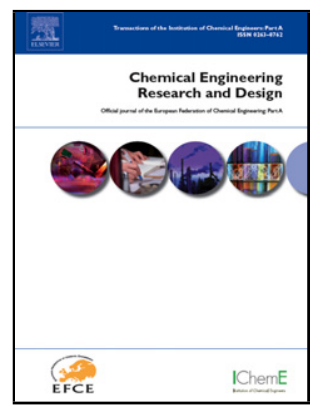
J. B. ten Kate, Georgios M Kontogeorgis, Flavio Manenti, Guy B Marin, Seyed Soheil Mansouri, Patrick M. Piccione, Ana Povoa, Manuel Andres Rodrigo, Bent Sarup, Eva Sorensen, Isuru A.

Udugama, John M. Woodley

PII:

S0263-8762(20)30010-1

DOI:

https://doi.org/10.1016/j.cherd.2020.01.008

Reference:

CHERD 3959

To appear in:

Chemical Engineering Research and Design

Received Date: $\quad 11$ November 2019

Revised Date: $\quad 29$ December 2019

Accepted Date: $\quad 3$ January 2020

Please cite this article as: Gani R, Bałdyga J, Biscans B, Brunazzi E, Charpentier J-Claude, Drioli E, Feise H, Furlong A, Geem KMV, de Hemptinne J-Charles, Kate AJBt, Kontogeorgis GM, Manenti F, Marin GB, Mansouri SS, Piccione PM, Povoa A, Rodrigo MA, Sarup B, Sorensen E, Udugama IA, Woodley JM, A multi-layered view of chemical and biochemical engineering, Chemical Engineering Research and Design (2020), doi: https://doi.org/10.1016/j.cherd.2020.01.008 
This is a PDF file of an article that has undergone enhancements after acceptance, such as the addition of a cover page and metadata, and formatting for readability, but it is not yet the definitive version of record. This version will undergo additional copyediting, typesetting and review before it is published in its final form, but we are providing this version to give early visibility of the article. Please note that, during the production process, errors may be discovered which could affect the content, and all legal disclaimers that apply to the journal pertain.

(C) 2020 Published by Elsevier. 


\title{
A multi-layered view of chemical and biochemical engineering
}

\author{
Rafiqul Gani*
}

PSE for SPEED Company, Skyttemosen 6, DK-3450 Allerod, Denmark and

Jerzy Bałdyga ${ }^{1}$, Béatrice Biscans ${ }^{2}$, Elisabetta Brunazzi ${ }^{3}$, Jean-Claude Charpentier ${ }^{4}$, Enrico Drioli ${ }^{5}$, Hermann Feise ${ }^{6}$, Andrew Furlong ${ }^{7}$, Kevin M Van Geem ${ }^{8}$, Jean-Charles de Hemptinne ${ }^{9}$, Antoon J. B. ten Kate $^{10}$, Georgios M Kontogeorgis ${ }^{11}$, Flavio Manenti ${ }^{12}$, Guy B Marin ${ }^{8}$, Seyed Soheil Mansouri ${ }^{11}$, Patrick M. Piccione ${ }^{13}$, Ana Povoa ${ }^{14}$, Manuel Andres Rodrigo ${ }^{15}$, Bent Sarup ${ }^{16}$, Eva Sorensen ${ }^{17}$, Isuru A. Udugama $^{11}$, John M. Woodley ${ }^{11}$

${ }^{1}$ Faculty of Chemical and Process Engineering, Warsaw University of Technology, ul. Waryńskiego 100645 Warsaw, Poland

${ }^{2}$ Crystallization Engineering and solid and particle processes, LGC -CNRS Université de Toulouse, France

${ }^{3}$ Department of Civil and Industrial Engineering, University of Pisa, Largo Lazzarino 2, 56122 Pisa, Italy

${ }^{4}$ Laboratoire Réactions et Génie des Procédés CNRS/ENSIC, Université de Lorraine, École Nationale Supérieure des Industries Chimiques, 1, rue Grandville B.P.20451 54001 Nancy Cedex France

${ }^{5}$ Institute on Membrane Technology (CNR-ITM), c/o University of Calabria, Via P. Bucci cubo 17/C, 87030 Rende CS, Italy

${ }^{6}$ President, European Federation of Chemical Engineering, DECHEMA, Theodor-Heuss Alle, Frankfurt, Germany ${ }^{7}$ Cogent Content Ltd., 29 Hawthorne Drive, Thornton, Leicestershire, LE67 1AW, UK

${ }^{8}$ Laboratory for Chemical Technology (LCT), Department of Materials, Textiles and Chemical Engineering, Ghent University, Technologiepark 125, 9052 Ghent, Belgium

${ }^{9}$ IFP Energies nouvelles ; 1 et 4, avenue de Bois-Préau ; 92852 Rueil-Malmaison Cedex - France

${ }^{10}$ Nouryon RD\&I, Zutphenseweg 10, 7418 AJ Deventer, Netherlands

${ }^{11}$ Department of Chemical and Biochemical Engineering, Technical University of Denmark, DK-2800 Kgs Lyngby, Denmark.

${ }^{12}$ Politecnico di Milano, Dipartimento CMIC "Giulio Natta", Piazza Leonardo da Vinci 32, 20133 Milano, Italy

${ }^{13}$ Pharmaceutical R\&D, F. Hoffmann-La Roche AG, Grenzacherstrasse 124, 4070 Basel, Switzerland

${ }^{14}$ Engineering and Management Department, Instituto Superior Técnico, Universidade de Lisboa, Av. Rovisco Pais • 1049-001 Lisboa, Portugal

${ }^{15}$ Department of Chemical Engineering. Universidad de Castilla- La Mancha. Campus Universitario s/n. 13071 Ciudad Real, Spain.

${ }^{16}$ Alfa Laval Copenhagen A/S, Maskinvej 5, DK-2860 Søborg, Denmark 
${ }^{17}$ Department of Chemical Engineering, University College London, Torrington Place, London WC1E 7JE, UK

* Corresponding author (rgani2018@gmail.com)

Graphical abstract

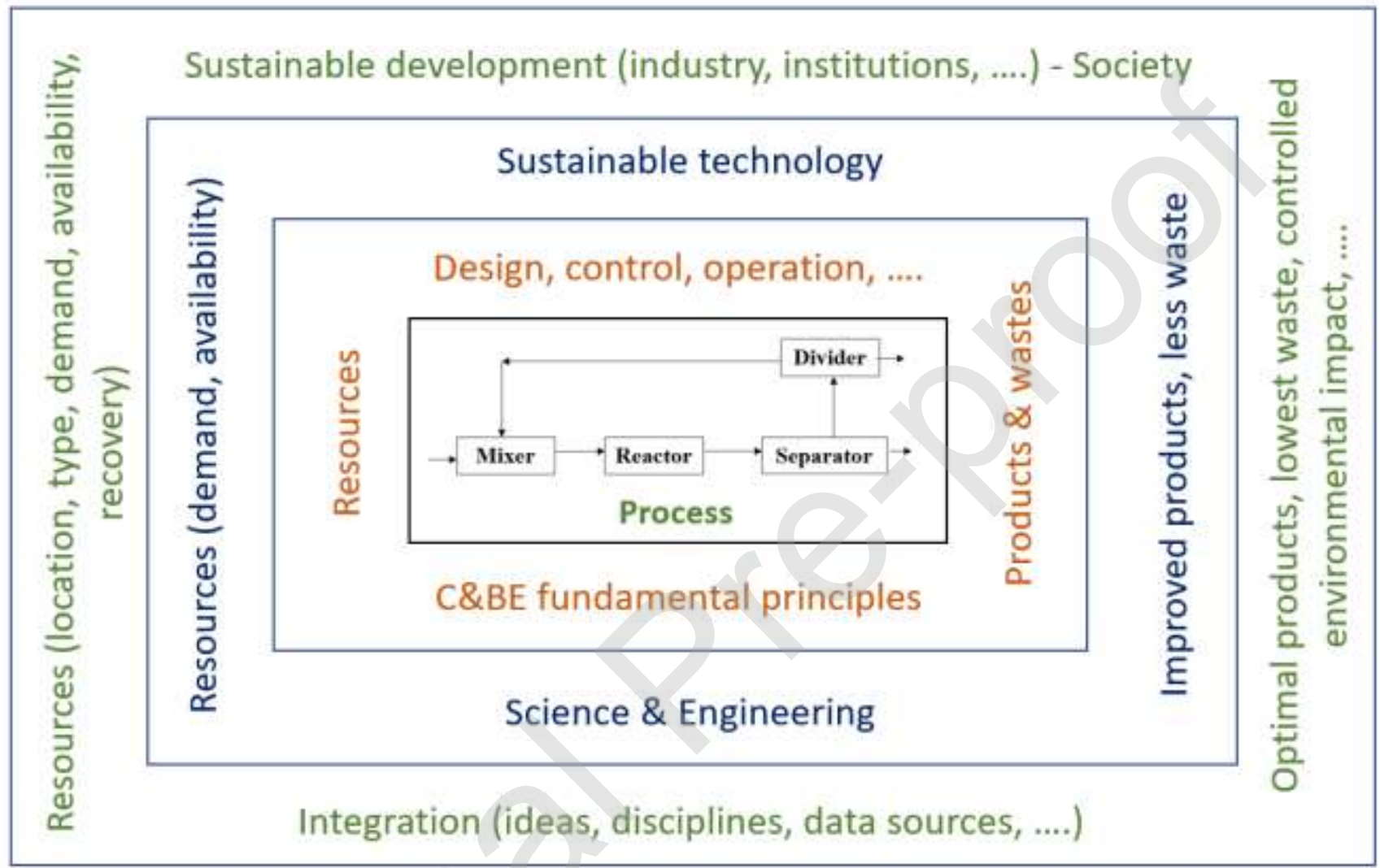

\section{Highlights}

- A multi-layered view of chemical and biochemical engineering (C\&BE) is given

- Aspects of research, education and practice are highlighted

- Perspectives in terms of current state and significance of C\&BE are presented

- Perspectives in terms of future scope and significance of $C \& B E$ are presented

\section{Abstract}

The contents of this article are based on the results of discussions the corresponding author has had since 2015 with the co-authors, who are members of academia and industry in Europe, on the scope and significance of chemical and biochemical engineering as a discipline. The result is a multi-layered view 
of chemical and biochemical engineering where the inner-layer deals with the fundamental principles and their application; the middle-layer deals with consolidation and expansion of the principles through a combination of science and engineering, leading to the development of sustainable technologies; and the outer-layer deals with integration of knowledge and collaboration with other disciplines to achieve a more sustainable society. Through this multi-layered view several important issues with respect to education, research and practice are highlighted together with current and future challenges and opportunities.

Keywords: Chemical and biochemical engineering; research; education;practice; multi-layered view

\section{Introduction}

Industrial chemical technology revolutionized the modern world in the $20^{\text {th }}$ Century, and now in combination with industrial biotechnology it is set to do the same in the $21^{\text {st }}$ Century. Underpinning these developments is the discipline of chemical and biochemical engineering ( $\mathrm{C} \& \mathrm{BE})$. The discipline applies, among others, the fundamental principles of thermodynamics, reaction stoichiometry and kinetics, biochemistry and cell biology as well as transport phenomena together with the laws of conservation of mass, energy and momentum to create better materials, products and processes that are useful to society. In other words, at a technical level chemical and biochemical $(\mathrm{C} \& \mathrm{~B})$ engineers work with unit operations (be it at industrial scale, pilot scale, micro-scale or nano-scale) for the purposes of chemical and/or biochemical synthesis followed by downstream separations, which are all based on phenomena such as thermodynamics, reactions (chemical, biochemical, or thermal conversions), transport (mass, heat and momentum). In this way, $\mathrm{C} \& \mathrm{~B}$ engineers solve problems related to synthesis, design, analysis, implementation, operation-control, optimization, etc., of chemical and biochemical processes needed to manufacture the products required by society. This implies that the scope and significance of C\&BE is potentially enormous. In a given case, the scope is defined by the raw materials that can be converted to the desired products through the corresponding manufacturing processes where resources such as energy are consumed, water is used and the environment is affected. Nevertheless, the conversion of the resources to products is in all cases incomplete and therefore the issue of recycle and regeneration of resources becomes increasingly important and urgent (Negro et al., 2018). Over the past decades, as the demand for better and more versatile products and their corresponding flexible manufacturing processes has increased, so has the need for increased knowledge on related topics that is perhaps not well understood in the context of application of C\&BE based technologies but are nevertheless very important. Moreover, society currently faces grand challenges like climate change, growing global population and resource limitations that require innovative solutions regarding the way products and services are provided. In this way, $\mathrm{C} \& \mathrm{BE}$ is also an evolving discipline.

Historically, chemical engineering came into existence more than a century ago by synthesizing the fundamental scientific disciplines of chemistry, physics and mathematics with mechanical engineering competences required for industrial processes and contributing, thereby, to the world's economic 
progress (Wei et al., 1979). Indeed, while chemical engineering has made enormous contributions as a discipline (and profession), it has also embraced rapid and dynamic technological changes and has frequently been at the center of emerging new developments (Butz and Tauscher, 2002). Today, perhaps more than at any other time in history, we face formidable challenges (Negro et al., 2018). But these challenges also represent unique opportunities such as exploring and exploiting new abundant resources (Wang and Krupnick, 2015); substituting and/or improving the exploitation of resources in current use (Christensen et al., 2008); delivering sustainable solutions related to energy (Chu and Majumdar, 2012), water (Gleick, 2016), environment (Allen et al., 2018) and food (Papargyropoulou et al., 2014); contributing to avoid danger and risk, for example, climate change (Monastersky, 2013) or accidents (Brunaud et al., 2019) and, optimizing the operation, distribution and safety of manufacturing processes (Grossmann, 2005).

The objective of this paper is to present a multi-layered view of chemical \& biochemical engineering, through which its scope and significance, as well as its future role can be better understood. This view highlights the important outcomes of chemical and biochemical engineering as a discipline as well as a profession. The inner core fundamental layer involves process-product related activities where application of the fundamental concepts of C\&BE help to design, build and operate manufacturing processes that convert specific raw materials to desired products. The middle interface consolidation layer involves resources-efficiency related activities where improved understanding of the concepts and combination of science and engineering lead to the development of new technologies that when applied, lead to more sustainable engineering solutions. The outer unifying layer involves society-challenges related activities where industrial development helps to address challenges that when resolved would lead to a more sustainable society. Here, integration of knowledge, such as ideas, disciplines etc., play a major role. The main issues, challenges and opportunities at each level are discussed with respect to education, research and practice related to each layer.

\section{The Multi-layered View}

The multi-layered view is shown in Figure 1, where three inter-connected layers are highlighted. The concept can be understood through the following logic; Horizontal - left: input of resources to the system, right: outcome in terms of conversion to products; Vertical - bottom: (intellectual) input from C\&BE, top: impact on the system due to increased knowledge and available products. Layers - innermost: core topics defining the discipline, outermost: topics that define the contributions of C\&BE to society.

In Figure 1, moving from left to right adds material, economic and societal value. That is, from resources (raw materials as well as utilities such as energy and water) higher valued products are obtained (innerlayer); considering demand and availability of these same resources, the products are further improved and the processes become more efficient (middle-layer); adding also considerations (for the same resources) such as resource location, type, recovery, etc., the optimal products with lowest wastes and 
controlled environmental impacts, etc., are obtained at various scales (plant, industrial parks, country, region, etc.). To obtain these incremental improvements, a better understanding of the concepts that lead to new technologies is needed. Moving from bottom to the top of the figure, input of knowledge leads to problem solutions. That is, fundamental knowledge of C\&BE helps to design, build and operate the manufacturing process (inner-layer); combination of science and engineering gives a better understanding that leads to the development of sustainable technologies (middle-layer); integration of knowledge from different disciplines providing new ideas and data sources contribute to sustainable development of society (measured in terms of institutions, industry, ecology, etc.).

These layers are strongly interactive, that is, demand from the outer layers require increased know how from the inner layers to meet them. For example, as the need for structured products like food, detergents, cosmetics, etc., grows, as pointed out by Cordiner (2004) and Hill (2004), the numerous operational steps involved with the processing of these products provide opportunities as well as challenges to find better, more reliable and innovative alternatives (Zhang et al., 2016). First, however, the involved phenomenamicrostructure-property-process relations need to be understood sufficiently through focused experimental work and subsequent experiment-based process analysis. The fundamental understanding gained together with experimental evidence could then be used to conceptualize and derive mathematical models for faster and more reliable process development. Also, as one moves from the inner layers to the outer, the scope and significance of the problems tackled, the solutions found and the knowledge required broadens. Therefore, the three layers together highlight aspects of incremental education, research and practice, as well as the impact on our society and on the global environment. Note that even though a topic or keyword is not listed in a specific layer, it does not mean they are not used in that layer. For example, the terms "resources" and "science \& engineering" are listed in the core and middle layers, respectively, to highlight their key-roles in employing the fundamental principles as well as consolidation and expansion of the scope and significance of $\mathrm{C} \& \mathrm{BE}$. Also, to find innovative solutions and to minimize the ecological impact and/or to maximize the societal benefits, even though resources such as energy, water, material, etc. are needed, human resources are also needed to develop technologies, methods, tools, etc., to design, construct and operate the processes and to distribute and/or supply the manufactured products. Similarly, the developments from the inner layers help to achieve sustainable industrial development and to educate-train the stake-holders by addressing the grand challenges through appropriate interdisciplinary and/or multidisciplinary approaches.

\section{Inner core fundamental layer: processes and products}

At the fundamental level, C\&BE involves the conversion of specific raw materials to desired chemicalsbased products through appropriate processing routes while also utilizing resources such as energy, water, materials, man-power, etc. to achieve the desired objectives. However, successful development of a desired chemical or biochemical product requires an economically feasible manufacturing process and vice versa. For best success, both the product and the process should be optimal. To achieve this, the knowledge input is process engineering that may include aspects of chemical kinetics; transport 
phenomena; unit operations; process integration; control and many more. Adjacent areas such as organic chemistry, analytical sciences, biology, mechanical engineering must also be drawn on, as appropriate. The connection between the product and the process is highlighted through Figure 2 (Zhang et al., 2016), where in addition to the traditional product-process connection, the application of the product for performance evaluation is considered, for example, use of a solvent for solvent-based separation or use of a solvent for product delivery, for instance, in delivery of an insect repellant as a liquid lotion. Note that the objective of the process is to produce the product defined by its molecular structure (for single species products), purity, state, etc., while the objective of the product is to deliver its functions (product application). The objective of product design, in this case, is to identify the molecular structure (for single species products) with the desired properties.

\section{Middle interface layer: science and engineering}

Raw materials and economically feasible processing routes are no longer sufficient to launch a successful product-process. Use of resources such as energy and water need to be optimized together with efficient management of raw materials supply-demand, economics, products distribution and environmental impacts. Safety issues, both related to risk avoidance for plant workers as well as for the neighborhood, is also of increasing concern. Innovative solutions for service provisions therefore need to be determined. This requires additional knowledge in terms of the integration of science and engineering leading to the development of innovative solution approaches to process integration and intensification as well as new ways to manage supply chains and to monitor economic, ecological and societal impacts of manufacturing processes and product use. The outcome could be sustainable technologies in terms of a reduced ecological footprint together with greater societal benefits while maintaining profitability. The inputs from fundamental sciences, the rational use of computational tools and focused experimental validation need to play important roles at this level. The improved understanding of the phenomena at all scales (including the core layer) need to be considered and integrated in order to be able to optimize the production processes such that significantly improved innovative solutions are obtained, employing new and more efficient unit operations. The combination of science and engineering in product-process development needs to play a key role, where increasing scientific focus may lead to smaller equipment sizes while increasing engineering focus may lead to larger scales of sustainable technologies. For example, in the area of micro-structured products, the key to success is to first identify the desired enduse properties of a micro-structured product at the small-scale, and subsequently to control product quality and production efficiency by manipulating the microstructure formation at the process scale leading not only to a novel product but also to less waste and lower energy consumption (Charpentier, 2003).

\section{Outer unifying layer: improved social benefits}


It is expected that within the next 20 years, the population on earth would stabilize to around 9 billion (Pereira et al., 2010); requiring 6-7 times increase of world GDP; which will require 5-6 times increase of existing production capacities for most commodities (steel, chemicals, lumber, etc.); 3.5 times increase in energy demand (7 times increase in electricity demand); very large increase in water demand. Costs related to $\mathrm{CO}_{2}$ emissions are estimated to be $7 \mathrm{GTC} / \mathrm{yr}$ to $26 \mathrm{GTC} / \mathrm{yr}$ (Vooradi et al., 2018) together with concomitant increase in knowledge requirement. Therefore, in the outer layer, the grand challenges (http://www.engineeringchallenges.org/challenges.aspx) in terms of availability of resources and raw materials need to be reconciled with sustainable development of society (https://sustainabledevelopment.un.org/). An alternative way to meet the sustainable development goals is to focus on improving the quality of manufactured products (or related services), which as a result would drive down the need for quantity while also ensuring that society (the consumer) gets to at least maintain their current quality of life and comfort.

To achieve this objective, a larger vision of the true needs of society with respect to the limited availability of resources needs to be implemented. With respect to C\&BE, this requires integration of chemical and biochemical engineering know-how together with other disciplines (e. g., sociology, ethics, political sciences, economics) and with many of the main actors (such as decision makers and decision influencers) of society. Prausnitz (2007) has emphasized this aspect together with the special role of the human dimension in $\mathrm{C} \& \mathrm{BE}$. The outcome is a set of optimal products generating minimum wastes and consuming less resources (raw material, energy, water, etc.) through more sustainable processes, that contributes to the education, training and practice of C\&BE, and thereby, to sustainable development of society.

\section{Interaction between layers}

Referring to Figure 1, the application of $\mathrm{C} \& \mathrm{BE}$ and the associated challenges identify opportunities and help to set targets for improvements in education, training and practice. To achieve these targets, science and engineering needs to come together to develop techniques, methods and tools through which sustainable and innovative products-processes can be designed and/or developed in the middle layer. However, to develop the techniques of the middle layers, the available knowledge in the core layer in terms of theory, concept and data need to be enhanced. The movement is from the core layer to the outer layers with feedback towards the inner layers for adjustment and/or refocus of targets. For example, education gives the $\mathrm{C} \& \mathrm{~B}$ engineer knowledge to practice and understand the fundamentals, which they employ for research in the middle layer to develop new techniques, which they employ in practice in the outer layer for the sustainable development of society. However, as the needs of society change, the fundamental concepts and the targets from the inner layers also need to be adjusted. Note also that education, research and practice may be applied at all layers, depending on the level or type of the institutions at which they are conducted. That is, the desires (targets) placed on C\&BE on the outer layer for expected improved social benefits are related to the technical and economic constraints placed by the middle layer as well as the understanding of the fundamental principles in the core inner-layer. This 
means all three layers are interconnected as any desire or constraints from the outer and/or middle layers respectively, could influence the scientific requirements placed on the inner layer while any development in the inner layer influences the outer layers and their ability to fulfil the constraints and/or desires.

\section{Education}

The key question in $\mathrm{C} \& \mathrm{BE}$ education is what skills, outcomes and knowledge are needed for the three cycle (BSc, MSc and $\mathrm{PhD}$ ) education program in the subjects of $\mathrm{C} \& \mathrm{BE}$. One option for the case of BSc and MSc degrees could be that the actions in the core layer of Figure 1 be linked to the core curriculum (for example, BSc), while the middle and outer layers could be linked to the advanced (related to the inner-core topics) and/or specialization topics not included in the inner-core (for example, an extended $\mathrm{BSc}$ or MSc). What is necessary is that $\mathrm{C} \& \mathrm{BE}$ students understand the basic concepts, scope and significance of the middle as well as the outer layers. One way to incorporate the additional knowledge from the outer layers into C\&BE education is through design and/or evaluation projects, where concepts such as ethics, sustainability, sustainable development and/or circular economy are included. The PhD degree on the other hand is concerned with mainly research and development at all layers based on the knowledge gained at the BSc and MSc levels, posing of new problems, addressing of current challenges and/or exploring available opportunities. An important issue is the depth of knowledge gained at each layer. The outcomes of the BSc and MSc education are knowledge and understanding; engineering analysis; design and practice; investigations; transferrable skills; and ability to solve problems. Therefore, topics from the middle and outer layers of Figure 1 are needed as a complement to the core curriculum. In this regard, the use of virtual laboratories (or innovative pedagogies) to cope with the growing number of students, combined with a lack of adequate pilot-scale educational facilities is an alternative worth considering. The drivers for developing a virtual laboratory are highlighted in Figure 3. Innovative pedagogical techniques that currently exist should be employed, both to motivate the younger generation that is keen on using new technologies as well as to benefit from a renewed content that addresses more explicitly their needs (adequate use of tools such as process simulators, data bases, social media, remote or distant learning, etc.).

Another key issue is how to equip $\mathrm{C} \& \mathrm{BE}$ students to adapt to innovative technologies that may come from areas outside of the scope of $C \& B E$. That is, how to widen the C\&BE curriculum with nontraditional topics such as: life science related topics (biochemical engineering, molecular biology and genetic engineering; pharmaceutical engineering; biomedical engineering; product engineering; material engineering; environmental engineering); interdisciplinary fields (energy and fuel engineering; membrane science, aerosol, colloids and interface, organometallic chemistry; catalysis); and management related to advanced technology (operations management; change management; knowledge management) without sacrificing the core or fundamental topics from the inner layer? As the C\&B engineers increase their knowledge and abilities, they are moving to the outer layers, gaining expertise in a wider range of disciplines. For example, they can increase their core competences in sciences related 
to separation; mixing of solids, gaseous and liquid materials; and transforming materials to more useful forms with the help of energy and/or catalysts, be they biogenic or non-biogenic. With this expertise the C\&B engineers should be able to design and operate industrial plants and play an important supportive role in a wide range of other sectors, from manufacturing to mining and health care, for example.

With respect to non-technical skills $\mathrm{C} \& \mathrm{~B}$ engineers need to develop skills in ethics, business, and administration that can help them, for example, in project management, budgeting, and economics. Also, ability to work as part of teams in multicultural and diverse environments needs to be developed. Adaptation is an important skill in a rapidly changing society and C\&B engineers should have the ability to handle different situations as well as respond to emergencies, if necessary. In general, courses on process and plant design, combined with or without product design, are well suited to meet these types of learning objectives. Further enhancing of the fundamentals is very important, especially across the different disciplines of chemical engineering as emphasized by Wu and Prausnitz (2019) on the particular role thermodynamics plays in connection to chemical engineering.

\section{Research}

Research activities are needed in every layer. Scientific advances in the inner core topics could provide a better understanding of the underlying principles leading to increased availability of data, more reliable theory-models and therefore, the development of more flexible model-based methods and tools. This in turn could increase the scope and significance of $\mathrm{C} \& \mathrm{BE}$. The objective of research activities in the outer layer is to understand the needs of the key societal stakeholders and to translate them to specific targets for development. In the middle and core layers, the objectives are to develop and apply techniques and technologies to realize the targets through appropriate combination of science and engineering, and new developments and understanding of the fundamental principles. That is, in the outer layer, the focus could mainly be on tackling the global challenges to ensure the sustainable survival of people (9+ billion) on earth with an acceptable standard of living by, for example, improving the standard of living and safety with minimal environmental and health impacts. Therefore, concepts such as sustainability, circular economy and resource recovery need to be integrated into product development, process design and retrofit activities, to name a few.

In the middle layer the established targets from the outer layer could result in the following developments/trends for technologies, which by no means is an exhaustive list, and also is not listed in terms of any priority:

- Use of industry 4.0 technologies of AI, machine learning and big data in improving manufacturing operations with the aim of reducing resource usage and improved production efficiencies (Venkatasubramanian, 2019). To this end concepts such as digital twins, hybridmodeling techniques, novel sensors that are currently under development should receive more attention (Rosen et al., 2015). To achieve appropriate rather than indiscriminate application of data science, awareness of digital technologies amongst chemical engineers should be fostered; 
project activities should also be undertaken using conscious decisions to balance first principles and data driven methods (Piccione, 2019).

- Development of flexible and smart manufacturing technologies so that manufacturing plants can be "re-tooled" to produce multiple products and change production (Kang et al., 2016) as preferences and desires from the outer layer change. Concepts such as disposable reactors (Glindkamp et al., 2010), micro reactors (Rossetti and Compagnoni, 2016) as well as noninvasive measurement techniques such as image analysis (Forte et al. 2019) and tomography (Tapp et al., 2003) currently under development in the inner layer could enable this movement.

- Innovative and efficient processing through intensification that can significantly reduce the energy and resource demand are concepts that are already developed (Tian et al. 2019), but their industrial implementation need to increase. Process intensification is a promising technology that can lead the way towards more sustainable process alternatives.

- Better management of sources of energy in terms of harvesting, storing and using renewable sources of energy is necessary. Electrification by taking advantage of intermittent renewable energy sources, such as solar and wind; energy storage in the form of chemicals can contribute to balancing supply and demand if chemical processes could be run even periodically. In this context electricity storage in the form of chemical bonds (hydrogen, ammonia, methanol, and dimethyl-ether) is an opportunity and a challenge. Another option is to consider transformation of chemical and electrical energy not only for fuel cells but also for innovative alternatives such as redox flow batteries.

In the core layer, the constraints from the middle layer and desires (targets) of the outer layer require fundamental research results from the core layer, for example (not listed in any priority):

- Conversion of raw materials through chemical- and/or bio-catalysis using new synthesis paths, which can give important commodity chemicals at reduced energy and/or increased atom efficiency should always have high priority. For example, use of green electrons in electro-chemical conversion of water, $\mathrm{CO}_{2}$, and $\mathrm{N}_{2}$ into fuels and base chemicals like hydrogen, carbon monoxide, methanol, di-Methyl-ether, light olefins and ammonia (Van Geem et al. 2019).

- Separation principles that can discover new ways to separate chemicals from difficult separation problems at reduced and/or low energy consumption, high separation efficiency, minimal use of external separating agents that are energy intensive, and/or extract important new ingredients from plants or biomass should continue to attract attention of researchers. Combining more than one separation technique into hybrid operations where each technique performs at its highest efficiency is an option worth investigating.

- Selection and design of functional materials that can have a reduced maintenance or replacement requirements, substitute the function of multiple materials and/or address any un-satisfied need of the outer layer (Cheng et al., 2011) are important for discovery of new processing routes and/or separation principles. Use of ionic liquids as environmentally acceptable separation agents and 
MOFs (Metal Organic Frameworks) and COFs (Covalent Organic Frameworks) for gas separations are alternatives worth investigating along with membranes.

- Better understanding of the phenomena and the domain system involving complex chemical and biochemical systems is necessary to develop more comprehensive modelling of the process (Klatt and Marquardt, 2009) and the associated properties of chemicals and materials. Of particular interest are the modelling of properties of structured products, solids and polymers; multiphase operations with complex chemical systems, such as electrolytes; as well as the complexity of living systems and the difficulties in understanding them.

\section{Practice}

Fundamentally, industry rewards and exemplifies the benefits of C\&BE by translating the discipline to value - and offering interesting and challenging careers to motivated individuals who pursue employment in the field. The mechanism for such value creation is exemplified in the various layers of Figure 1, starting with the outer layer: identifying which grand challenges it needs to address to achieve sustainable industrial development and thereby, improving circularity. Industry is ideally placed to do so by drawing on the skills from the inner layers, since it will have the economic and ecological insights and remit to ensure that important technologies are adopted in economically viable ways, thereby ensuring sustainable development. The combination of science and engineering to help develop commercially successful technology, in a sense, is the very definition of industry's remit, in addition to maintenance of its existing operations. To achieve this goal, at the innermost layer, skills such as handling of resources, feasibility of products, economic feasibility, etc., will need to be developed. In doing so, industry will of course link to both academic and government institutions to: a) set developmental challenges; b) identify collaboration opportunities to make efficient use of limited resources; c) encourage transfer technology; d) identify and share the capability challenges needed by practicing C\&B engineers. It is also important to point out that in the next decades, increasing industry-industry partnerships are to be expected as well, especially in supply chain, mirroring the need for a greater set of organizational relationships within any company. The demand from the world's ever-growing population is towards more socially responsible corporations, which may be a factor that should be considered by the players from the industrial sectors.

Table 1 lists forms of industrial practice in terms of what they do or use, what they need or consume and what they give to society or results. It can be noted that the different types of industrial practices are connected to each other. That is, the result (what they give) from one layer is used as input by another. The manufacturing companies will produce products that society needs using technologies developed by engineering companies and where equipment designed-developed by equipment companies are employed. Also engineering companies use tools developed by software companies as well as research results from academia. The services of consulting companies are needed by all other companies. The objective for all of them, however, should be to achieve sustainable development and/or circularity. 
Several routes could be followed in order to achieve the above objectives. C\&BE subject to constraints (recycling and re-use of matter and energy, sustainable and safe processes, intelligent and personal products, full techno-commercial evaluations including real-world issues like tax laws, environmental, health and safety regulations) implies a top-down approach, which points to upstream scientific and technological developments. In a complementary way, a bottom-up research could also be considered for methodological and paradigm developments, in order to tackle the future challenges. Innovation will be the result from both approaches. To encourage diversity, gender issues must also be tackled.

\section{Perspectives}

The scope and significance of $\mathrm{C} \& \mathrm{BE}$ is enormous and it is not the objective of this article to provide a comprehensive list. However, perspectives on a few selected topics that we think have attracted current attention and could also be important in future are discussed briefly. It is important to note that the way in which industrial plants are built and operated in the $C \& B E$ sector is changing due to concepts such as disposable reactors and micro reactors (Roberge et al., 2008) allowing far more flexibility in the manufacturing process. Conversion of batch to continuous processing is steadily becoming more routine. Combining these concepts with the emerging fields of 3-D printing and functional materials allow for smart manufacturing practices to be established. Moreover, the influence of industry 4.0 (Kolberg and Zühlke, 2015), which encapsulates concepts of big data and artificial intelligence is changing the goal post of efficient process operations (Piccione, 2014). Figure 4 shows the engineering challenges in the next 10 years. According to this figure the relevance of various digital applications (model-based approaches) today and in 2025 are demonstrated with a score showing how they will become more important in the coming years (Keller, 2018). Specific activities to help bridge chemical engineering and data science are available (Piccione, 2019).

Likewise, digitalization has been an integral part of $C \& B$ development in the past decades be it the use of "digital" process controls as opposed to "pneumatic" controls; the development of process simulations; process synthesis and other tools in the domain of process systems engineering (PSE). These developments are now part of the standard set of "tools" that C\&B engineers use routinely in their dayto-day work. With computing power still doubling roughly every few years, as predicted by Moore's law (Schaller, 1997), the speed and reliability of PSE methods \& tools continue to improve, allowing C\&BE engineers to solve problems of increased complexity at higher fidelity in real time. In addition, Industry 4.0 and the big data concepts are becoming ever more prominent in the domain of C\&BE. (Venkatasubramanian, 2019; Piccione, 2019).

The perspectives of $\mathrm{C} \& \mathrm{BE}$ are highlighted through the following two issues and their discussions in terms of opportunities and challenges. 


\section{Current scope \& significance of $C \& B E$}

\section{Products and their manufacturing processes (core)}

The main questions here (related to chemicals-based products) are what to make, when or why to make it and how to make it? The first two questions are related to the products and the last question is related to the associated process. Even though the chemicals-based products and their manufacturing processes are related, the education, research and practice do not always address the same issues. Using the classification of chemical products by Cussler \& Moggrige (2001), Table 2 highlights the main reasons. It can be noted that until recently, most of the C\&BE activities were focused on the production of commodity chemicals where process is the key. With the expansion of $\mathrm{C} \& \mathrm{BE}$ to molecular and functional products and chemicals-based devices, the scope and significance of $C \& B E$ education, research and practice related to products and their sustainable processes have also increased.

Other issues that could also play a major role in defining the scope and significance of C\&BE are briefly highlighted below:

- The challenge is to design and develop novel and innovative chemical products of better quality and longer durability and the opportunity is the need for these products some of which can be developed through integrated experiment and model-based techniques, leading to reduction in time and cost in their development (Liu et al., 2019; Zhang et al., 2018).

- Interest in bio-based economy through new bio-catalytic processes converting biomass to valuable raw materials is increasing rapidly (van Dam et al., 2005). Direct biological production through genetically modified cells and protein engineered enzymes is showing promise, while, combined hybrid biochemical and chemical transformations continues to be attractive (Davy et al., 2017; Sanford et al., 2016; Woodley 2019).

- The separation and conversion of by-products needs to be strengthened, in particular, in bio-based productions with inspiration from traditional chemical engineering processes. Also, the introduction of intensified process designs and the introduction of separation technologies to capture secondary by-products of value which are currently discarded, need to be considered (Atasoy et al., 2018).

\section{Resources (middle)}

The main questions to ask here are which resources to use, for what purpose and how sustainable are they? Not counting the manpower resources, as Figure 5 highlights, $C \& B E$ uses two types of resources - a) those that are converted to useful chemicals-based products through a specific processing route, for example, crude oil or biomass; and b) those that are needed to operate the processing routes, for example, energy (fossil fuel, solar, wind-power, etc.), water and material (metals, catalysts, solvents, etc.). Choice of the processing route and the form of resource are important issues (see below) that are the subject of much research, but not so much in education and practice. There is actually a third type of resources the human resource, the development of which is related to education and their use is related to practice. 
Other issues that could also play a major role are briefly highlighted below:

- Fundamental transition from fossil to alternative sources of energy over the next decades through increased use of green energy sources and increased energy efficiency has started (Dresselhaus and Thomas, 2001). Moreover, the improvement of energy usage through a combination of renewable and non-renewable resources need to be further investigated (Agrawal et al. 2019) in particular the storage and management of energy. Since the global energy and mobility still rely on oil derivatives, the efficient usage of these resources through the introduction of hybrid technologies or the complete elimination of its use in some sectors (such as automobile industry) will allow the remaining resources to be stretched (Ediger et al., 2007).

- Even though competition for existing material and energy resources would remain, the supply chain issues related to water will need to be carefully monitored. The management of water resources through designing processes to be water efficient and recovery of water through recovery technologies implicitly as a part of the engineering process design (Glieck, 2016). Opportunities for environmentally efficient acquisition of materials such as rare earth metals and their efficient use, recovery and recycle needs to be investigated (Binnemans et al., 2013).

- The efficient cultivation of food and livestock, which enable the reduction of need for limited arable land available and the development of technologies to reduce the food waste through targeted application of process and materials technologies (Kummu et al., 2012). In parallel, analytics should play an increasing role in mapping occurrences of unwanted trace chemicals in our food and environment (for example, air and water) combined with their adverse health effects, which in turn, puts increasing demands on product formulation and their production process.

\section{Societal (outer)}

Based on Figure 5, the following question could be asked - is C\&BE addressing the challenges related to climate change, energy, water and food or is it adding to the problem? Surely, as the Barcelona Declaration from 2017 (Negro et al., 2018) outlined, we all have the responsibility to address these challenges. Some notable developments are highlighted below:

- Strong demand for renewable energy sources and storage technology is an area of active interest to the society and must be addressed. This also means the adaptation of potential renewable energy technologies as well as storage technologies, which would benefit from government subsidies as well as support from the public, making their implementation easier.

- Health-care demands new advanced instrumentation and materials, and the push for a bottom-up approach for improved early diagnosis and treatment of disease (Aguado et al., 2018). This push can also be used in moving from a treatment oriented medical system to a predictive and precisionbased early diagnostic system to allow the move towards prevention based medical systems. Here 
model-based approaches and data-driven tools developed within PSE discipline can facilitate future developments.

- Sustainable production and distribution of food and other products becomes very important (Validi et al., 2014), especially considering the steady increase of the human population and the scarcity of resources in general. This has knock-on effects on energy usage, water usage as well as land usage. To this end from a societal point of view the holistic and complete management of the Water - Energy - Food nexus as well as the efficient management of land usage would be important.

\section{Future scope \& significance of C\&BE}

\section{Improvements of processes based on current needs}

Energy related issues will continue to dominate research and development with C\&BE (Vooradi et al. (2018). New routes to fuels, fine chemicals and pharmaceuticals that are all based on 'green' feedstocks would contribute to tackling the grand challenges of energy, water, food and environment. Waste and its hazards would also be minimised. Therefore, there is a need for systematic identification of optimal processing pathways that lead to more sustainable production processes and supply chains (You et al., 2012). Achieve a state of clean, zero-waste producing processes in operation. The topics that could also play a major role are highlighted below:

- Intensification of chemical and biochemical processes will provide the means to develop novel more sustainable process alternatives (Stankiewicz and Yan 2019). However, issues related to design and control of such multi-functional unit operations need to be addressed at different levels of aggregation, i.e., phenomena, task and unit operations levels through systematic approaches that allow identification of novel intensified alternatives (Tula et al. 2019). Rapid developments in labon-a-chip technology could lead to (micro/nano) sensors and measuring devices as well as highspeed analysis methods for single cell genomics, transcriptomic, and proteomics.

- New reactor concepts, and designs controlling reactions in space and time will lead to increased productivity, reduced waste, lower environmental impact and lower cost of manufacturing (Hessel et al., 2013). In this essence, combining flow chemistry approaches with PSE methods and tools could lead to interesting new developments. In this combined mind-set, flow chemistry and microchemistry would allow developments in reaction engineering, while PSE methods and tools would reduce the time, cost and resources for experiments by systematically reducing the search space of alternatives to be tested through a model-based approach. The routine availability of continuous manufacturing approaches for many unit operations and their integration could lead to additional flexibility operational flexibility.

- Multi-scale modelling and optimization of phenomena from atomic scales into unit operations and supply chain management with side-by-side modelling and experimentation approaches need to play a leading role. In this context, for example, computational chemistry can be used to bring 
understanding at molecular level and assist in developing new products. This can be used to reliably develop new unit operation concepts for production and supply chains for distribution of such novel products. Thereby, reducing the experimental costs and efforts and leading towards a more rapid product development from concept to implementation. However, solving such problems requires development of innovative solution strategies in line with advances in computer science.

\section{Development of processes for future needs (products)}

Energy will continue to play an important role in the development of processes for the future. Energy demands and how they are supplied through sustainable conversion and storage technologies, such as the combination electrolyzers/fuel cells and new battery technologies with regard to large scale battery implementation to store renewable energy generated (for example, Redox flow batteries) will attract much attention, including the storage of large amounts of energy. The topics that could also play a major role are highlighted below:

- New catalysts and technologies for enabling high-efficiency materials production, for example the development of direct process pathway to convert hydrogen peroxide to propylene oxide technologies, which was in principle enabled through the development of a new catalyst and related process technologies. In addition, recent developments in electrified methane reforming for greener industrial hydrogen production seem to be very promising (Wismann et al., 2019). Smart material assembly through molecular control will be a critical enabler for this theme.

- Recovery/recycling of used product as precursor or source of raw material, which allows the realization of the zero-waste objective of circular economy (Geissdoerfer et al., 2017). Development of processes, approaching the 'zero-waste' target at minimum energy consumption (Straathof et al 2019). Use the concept of atomic economy in the development of new processes and in the re-design of existing technologies. Re- thinking processes based on the concept of circular economy, not only raw materials and products but also equipment and energy supply.

- Computational science to enable more developments of in silico techniques leading to "quality by understanding" of products and processes that rely on detailed, scalable quantitative descriptions. In a related vein, sustainability requirements, especially with respect to environmental impact, keep increasing. It will be important to come up with frameworks that can be flexibly and quickly adapted in optimization methods.

- New manufacturing and associated field techniques will be required to realize the potential of personalized health care. Electrochemical technologies which avoids the use of reagents to oxidize or reduce a raw matter and change them by electricity, avoiding the formation of undesirable byproducts and/or wastes. Nature inspired approach to reactor and catalysis engineering (Coppens 2012) and more nature inspired chemical engineering leading to new design methodologies for sustainability (Trogadas and Coppens 2020) point to exciting new developments. A major challenge and opportunity here are to understand and learn from the living systems to develop these new and innovative design methodologies. 


\section{Sustainable technologies}

Circular economy requires or is completely engaged and linked with circular engineering, especially to meet the societal grand challenges. In future, instead of using the concept of circular economy, it could be more relevant or appropriate to use the concept of the circular economy-engineering (especially in our case, the circular economy-C\&BE).

The topics that could also play a major role are highlighted below:

- $\mathrm{CO}_{2}$ management including capture, conversion, utilization and storage, new (catalytic) chemistries, which can be integrated with concepts such as $\mathrm{CO}_{2}$ management. These concepts control the chemical reaction pathways at molecular level, aiming at 100\% atom efficiency and zero waste. This could be aided by converting by products such as $\mathrm{CO}_{2}$ into secondary products or, or by transforming it into carbonates with later deep storage to prevent its accumulation on the surface of earth, provided no adverse effects are caused by the deep storage.

- Feedstocks management, in particular, use of biological feedstocks through a combination of techniques - recycling of (communal) wastes and conversion of complex biomass feedstocks into chemicals, purification and desalination technologies for drinking water supply and recyclable construction materials (building, cars, etc.), to name a few, need to be studied (Clomburg et al 2017; Sheldon 2014).

- Energy management, such as affordable, robust, sustainable-across-the-entire-lifecycle solar power as probably the only likely long-term sustainable energy source for humanity needs more attention. At the same time sustainable management of all energy sources for optimal demandsupply of energy should be incorporated with concepts such as circular economy, smart manufacturing and zero-emission.

- Water management, in particular, supply and distribution of water for different needs and applications, such as, water that is safe for drinking, water for washing-cleaning, water for industrial manufacturing, water for heating-cooling and many more, needs urgent attention. While there is an abundance of water on earth, this availability is not uniform geographically and requires further processing before use. Therefore, new technologies for energy efficient water treatment, reduction of fresh water demand, etc., allowing better management of water resources are needed.

\section{Conclusions}

Because of their broad interdisciplinary knowledge and their key role in developing, operating and managing the industrial pillars of society as well as their professional link to many sectors, chemical and biochemical $(\mathrm{C} \& \mathrm{~B})$ engineers are in a pivotal position to help society shape a sustainable future. As professional experts and active responsible citizens, they can provide guidance, information and leadership to a society that has to meet the grand challenges of this century. Their expertise will be an essential contribution to the necessary interdisciplinary effort that includes all actors of society. C\&B interdisciplinary and multidisciplinary engineers are in a pivotal position to help society shape a 
sustainable future with the zero-waste and minimum energy consumption objectives of circular economy. They will be engaged in the future, in the design of the factory of the future with the use of industry 4.0 technologies to improve manufacturing operations by reducing resources and energy usage and improved production, thus leading to the design of sustainable technologies, that is, circular economy-engineering.

An important immediate activity is to define the grand challenges that society faces now, and hence to identify the main opportunities for C\&BE. C\&B engineers can exploit their services in education, industry or government to serve society - whether by finding sustainable (economic, social, ecologic) and/or technical solutions to the grand societal challenges; safeguarding the industrial economic base (products, processes, jobs) in competition with other regions and their geopolitical difference; or by promoting good engineering sense in the evaluation of new opportunities and challenges. By raising the recognition of the value engineers bring to society, young people will be motivated and encouraged to study and practice $\mathrm{C} \& \mathrm{BE}$. Their conceptualization skills across many disciplines and ability to break problems down into unit operations and physicochemical processes will be sure to be value adding.

As experts in the management of mass flows, energy efficient operations as well as the management of supply chains and the interactions between man and nature the impact of C\&B engineers should not be restricted to shaping a sustainable industrial system, but should reach far into planning and implementing future smart cities and regions as well as providing strong support to the health care of the future. They should be in a position to influence the decision makers as well as help make important decisions on issues such as education policy, research directions, environmental and safety regulations, resources management and many more. It should be noted that while techno-economic solutions can be found to make a desired product and its manufacturing process more sustainable, unless the decision makers restrict the demand or production rate, the product might still become unsustainable because of increased consumption and consequent depletion of resources.

Finally, we hope we have given a global view of C\&BE, which the reader may interpret differently at specific geographical locations. We expect the educators and practitioners of C\&BE to use the multilayered view to find the balance of topics at each level that suits best their particular needs and background at their geographical location.

\section{Declaration of interests}

The authors declare that they have no known competing financial interests or personal relationships that could have appeared to influence the work reported in this paper. 


\section{References}

Agrawal, R., 2019, Chemical Engineering for a Solar Economy, Chemical Engineering Science 210, 115215. doi: 10.1016/j.ces.2019.115215

Aguado, B.A., Grim, J.C., Rosales, A.M., Watson-Capps, J.J., Anseth, K.S., 2018. Engineering precision biomaterials for personalized medicine. Science Translational Medicine 10, eaam8645. doi:10.1126/scitranslmed.aam8645

Allen, M.R., O.P. Dube, W. Solecki, F. Aragón-Durand, W. Cramer, S. Humphreys, M. Kainuma, J. Kala, N. Mahowald, Y. Mulugetta, R. Perez, M.Wairiu, and K. Zickfeld, 2018: Framing and Context. In: Global Warming of $1.5^{\circ} \mathrm{C}$. An IPCC Special Report on the impacts of global warming of $1.5^{\circ} \mathrm{C}$ above pre-industrial levels and related global greenhouse gas emission pathways, in the context of strengthening the global response to the threat of climate change, sustainable development, and efforts to eradicate poverty [Masson-Delmotte, V., P. Zhai, H.-O. Pörtner, D. Roberts, J. Skea, P.R. Shukla, A. Pirani, W. Moufouma-Okia, C. Péan, R. Pidcock, S. Connors, J.B.R. Matthews, Y. Chen, X. Zhou, M.I. Gomis, E. Lonnoy, T. Maycock, M. Tignor, and T. Waterfield https://www.ipcc.ch/site/assets/uploads/sites/2/2019/05/SR15_Chapter1_Low_Res.pdf

(eds.)].

Atasoy, M., Owusu-Agyeman, I., Plaza, E., Cetecioglu, Z., 2018. Bio-based volatile fatty acid production and recovery from waste streams: Current status and future challenges. Bioresource Technology 268, 773-786. doi:10.1016/j.biortech.2018.07.042

Binnemans, K., Jones, P.T., Blanpain, B., Van Gerven, T., Yang, Y., Walton, A., Buchert, M., 2013. Recycling of rare earths: a critical review. Journal of Cleaner Production 51, 1-22. doi:10.1016/j.jclepro.2012.12.037

Brunaud, B., Laínez-Aguirre, J.M., Pinto, J.M., Grossmann, I.E., 2019. Inventory policies and safety stock optimization for supply chain planning. AIChE Journal 65, 99-112. doi:10.1002/aic.16421

Butz, P., Tauscher, B., 2002. Emerging technologies: chemical aspects. Food Research International 35, 279-284. doi:10.1016/S0963-9969(01)00197-1

Charpentier, J., 2003. The Future of Chemical Engineering in the Global Market Context: Market Demands versus Technology Offers. Kem. Ind. 52, 397-419.

Christensen, C.H., Rass-Hansen, J., Marsden, C.C., Taarning, E., Egeblad, K., 2008. The Renewable Chemicals Industry. ChemSusChem 1, 283-289. doi:10.1002/cssc.200700168

Chu, S., Majumdar, A., 2012. Opportunities and challenges for a sustainable energy future. Nature 488, 294-303. doi:10.1038/nature11475

Clomburg, J.M., Crumbley, A.M., Gonzalez, R., 2017. Industrial biomanufacturing: The future of chemical production. Science 355, aag0804. doi: 10.1126/science.aag0804

Cordiner, J.L., 2004. Challenges for the PSE community in formulations. Computers \& Chemical Engineering 29, 83-92. doi:10.1016/j.compchemeng.2004.07.024

Coppens, M. O., 2012, A nature inspired approach to reactor and catalysis engineering, Current Opinion 
in Chemical Engineering, 1(3), 281-289.

Cussler, E.L., Moggridge, G.D., 2001. Chemical Product Design. USA: Cambridge University Press.

Davy, A.M., Kildegaard, H.F., Andersen, M.F., 2017. Cell factory engineering. Cell Systems 4, 262-275. doi: 10.1016/j.cels.2017.02.010

Dresselhaus, M.S., Thomas, I.L., 2001. Alternative energy technologies. Nature 414, 332-337. doi: $10.1038 / 35104599$

Ediger, V.Ş., Hoşgör, E., Sürmeli, A.N., Tatlıdil, H., 2007. Fossil fuel sustainability index: An application of resource management. Energy Policy 35, 2969-2977. doi:10.1016/j.enpol.2006.10.011

Forte, G., Albano, A., Simmons, M.J.H., Stitt, H.E., Brunazzi, E., Alberini, F., 2019. Assessing Blending of Non- Newtonian Fluids in Static Mixers by Planar Laser- Induced Fluorescence and Electrical Resistance Tomography. Chemical Engineering and Technology, 42(8), 1602-1610.

Geissdoerfer, M., Savaget, P., Bocken, N.M.P., Hultink, E.J., 2017. The Circular Economy - A new sustainability paradigm? Journal of Cleaner Production 143, 757-768. doi:10.1016/j.jclepro.2016.12.048

Gleick, P.H., 2016. Water strategies for the next administration. Science. doi:10.1126/science.aaj2221

Glindkamp, A., Riechers, D., Rehbock, C., Hitzmann, B., Scheper, T., Reardon, K.F., 2009. Sensors in Disposable Bioreactors Status and Trends. In: Eibl R., Eibl D. (eds) Disposable Bioreactors. Advances in Biochemical Engineering / Biotechnology, vol 115. Springer, Berlin, Heidelberg. doi:10.1007/10_2009_10

Grossmann, I., 2005. Enterprise-wide optimization: A new frontier in process systems engineering. AIChE Journal 51, 1846-1857. doi:10.1002/aic.10617

Hessel, V., Kralisch, D., Kockmann, N., Noël, T., Wang, Q., 2013. Novel Process Windows for Enabling, Accelerating, and Uplifting Flow Chemistry. ChemSusChem 6, 746-789. doi:10.1002/cssc.201200766

Hill, M., 2004. Product and process design for structured products. AIChE Journal 50, 1656-1661. doi:10.1002/aic.10293

http://www.engineeringchallenges.org/challenges.aspx

https://sustainabledevelopment.un.org/

Kang, H.S., Lee, J.Y., Choi, S., Kim, H., Park, J.H., Son, J.Y., Kim, B.H., Noh, S. Do, 2016. Smart manufacturing: Past research, present findings, and future directions. International Journal of Precision Engineering and Manufacturing-Green Technology 3, 111-128. doi:10.1007/s40684-0160015-5

Klatt K-U, Marquardt W., 2009, Perspectives for process systems engineering - per-sonal views from academia and industry. Comput Chem Eng 33, 536-50.

Keller, W. 2018. Berufe 4.0 - Wie Chemiker und Ingenieure in der digitalen Chemie arbeiten, Berufe 4.0 - Ergebnisse, White Paper, https://www.gdch.de/fileadmin/downloads/Netzwerk_und_Strukturen/Fachgruppen/Vereinigung_f 
uer_Chemie_und_Wirtschaft/whitepaper_initiative_berufe_4.0_2018.pdf

Kolberg, D., Zühlke, D., 2015. Lean Automation enabled by Industry 4.0 Technologies, in: IFACPapersOnLine 48 (3), 1870-1875. doi:10.1016/j.ifacol.2015.06.359

Kummu, M., de Moel, H., Porkka, M., Siebert, S., Varis, O., Ward, P.J., 2012. Lost food, wasted resources: Global food supply chain losses and their impacts on freshwater, cropland, and fertiliser use. Science of The Total Environment 438, 477-489. doi:10.1016/j.scitotenv.2012.08.092

Liu, Q., Zhang, L., Liu, L., Du, J., Tula, A.K., Eden, M., Gani, R., 2019. OptCAMD: An optimizationbased framework and tool for molecular and mixture product design. Computers \& Chemical Engineering 124, 285-301. doi:10.1016/j.compchemeng.2019.01.006

Monastersky, R., 2013. Global carbon dioxide levels near worrisome milestone. Nature 497, $13-14$. doi:10.1038/497013a

Negro, C., Garcia-Ochoa, F., Tanguy, P., Ferreira, G., Thibault, J., Yamamoto, S., Gani, R., 2018. Barcelona Declaration - 10th World Congress of Chemical Engineering, 1-5 October 2017. Chemical Engineering Research and Design 129, A1-A2. doi:10.1016/j.cherd.2017.12.035

Papargyropoulou, E., Lozano, R., K. Steinberger, J., Wright, N., Ujang, Z. Bin, 2014. The food waste hierarchy as a framework for the management of food surplus and food waste. Journal of Cleaner Production. doi:10.1016/j.jclepro.2014.04.020

Pereira, H.M., Leadley, P.W., Proenca, V., Alkemade, R., Scharlemann, J.P.W., Fernandez-Manjarres, J.F., Araujo, M.B., Balvanera, P., Biggs, R., Cheung, W.W.L., Chini, L., Cooper, H.D., Gilman, E.L., Guenette, S., Hurtt, G.C., Huntington, H.P., Mace, G.M., Oberdorff, T., Revenga, C., Rodrigues, P., Scholes, R.J., Sumaila, U.R., Walpole, M., 2010. Scenarios for Global Biodiversity in the 21st Century. Science 330, 1496-1501. doi:10.1126/science.1196624

Pham, T.P.T., Kaushik, R., Parshetti, G.K., Mahmood, R., Balasubramanian, R., 2015. Food waste-toenergy conversion technologies: Current status and future directions. Waste Management 38, 399408. doi:10.1016/j.wasman.2014.12.004

Piccione, P.M., 2014. Industrial Reflections on Modelling of Fine Chemicals and Seeds. Process/Product Design, Chemical Engineering Research and Design 34, 212-224. doi:10.1016/B978-0-444-634337.50022-5

Piccione, P.M., 2019, Realistic interplays between data science and chemical engineering in the first quarter of the 21st century: Facts and a vision, Chemical Engineering Research and Design, 147, 668-675.

Prausnitz, J. M., 2007, Athena, Hercules and Nausica: Three dimensions of chemical engineering in the twenty-first century. Fluid Phase Equilibria, 261(1-2), 3-17)

Roberge, D.M., Zimmermann, B., Rainone, F., Gottsponer, M., Eyholzer, M., Kockmann, N., 2008. Microreactor Technology and Continuous Processes in the Fine Chemical and Pharmaceutical Industry: Is the Revolution Underway? Organic Process Research \& Development 12, 905-910. doi:10.1021/op8001273

Rosen, R., von Wichert, G., Lo, G., Bettenhausen, K.D., 2015. About The Importance of Autonomy and Digital Twins for the Future of Manufacturing. IFAC-PapersOnLine 48, 567-572. 
doi:10.1016/j.ifacol.2015.06.141

Rossetti, I. \& Compagnoni, M. 2016 Chemical reaction engineering, process design and scale-up issues at the frontier of synthesis: Flow chemistry. Chemical Engineering Journal 17, 296, 56 - 70.

Sanford, K., Chotani, G., Danielsen, N., Zahn, J.A., 2016. Scaling up of renewable chemicals. Current Opinion in Biotechnology 38, 112-122. doi: 10.1016/j.copbio.2016.01.008

Schaller, R.R., 1997. Moore's law: past, present and future. IEEE Spectrum 34, 52-59. doi:10.1109/6.591665

Sheldon, R.A., 2014. Creen and sustainable manufacture of chemicals from biomass: state of the art. Green Chemistry 16, 950-963. doi: 10.1039/c3gc41935e.

Stankiewicz, AI, Yan, P., 2019, The missing link unearthed: Materials and process intensification. Industrial \& Engineering Chemistry Research 58 (22), 9212-9222. doi: 10.1021/acs.iecr.9b01479

Straathof, A.J.J., Wahl, S.A., Benjamin, K.R., Takors, R., Wierckx, N., Noorman, H., 2019. Grand research challenges for sustainable industrial biotechnology. Trends in Biotechnology 37, 10421050. doi: 10.1016/j.tibtech.2019.04.002.

Tapp, H. S., Peyton, A. J., Kemsley, E. K., Wilson, R. H., 2003, Chemical engineering applications of electrical process tomography, Sensors and Actuators B: Chemical, 92, 17-24

Tian Y, Demirel SE, Hasan MMF, Pistikopoulos EN. 2018, An overview of process systems engineering approaches for process intensification: State of the art. Chemical Engineering \& Processing: Process Intensification. 133, 160-210. doi: 10.1016/j.cep.2018.07.014

Trogadas, P., Coppens, M. O, 2020, Chapter 2 - Nature-Inspired Chemical Engineering: A New Design Methodology for Sustainability, In: Szekely G., Livingston A. (eds) Sustainable Nanoscale Engineering, 19-31. doi: 10.1016/B978-0-12-814681-1.00002-3.

Tula, A.K, Eden, M. R., Gani, R., 2020, Computer-Aided Process Intensification: Challenges, Trends and Opportunities, AIChE Journal, 66, e16819. doi:10.1002/aic.16819.

Validi, S., Bhattacharya, A., Byrne, P.J., 2014. A case analysis of a sustainable food supply chain distribution system-A multi-objective approach. International Journal of Production Economics 152, 71-87. doi:10.1016/j.ijpe.2014.02.003

van Dam, J.E.G., de Klerk-Engels, B., Struik, P.C., Rabbinge, R., 2005. Securing renewable resource supplies for changing market demands in a bio-based economy. Industrial Crops and Products 21, 129-144. doi:10.1016/j.indcrop.2004.02.003

Van Geem, K. M, Galvita, V. V, Marin, G. B., 2019, Making chemicals with electricity, Science, 364 (6442), 734-735

Venkatasubramanian, V., 2019. The promise of artificial intelligence in chemical engineering: Is it here, finally? AIChE Journal 65, 466-478. doi:10.1002/aic.16489

Vooradi, R., Bertran, M.-O., Frauzem, R., Anne, S.B., Gani, R., 2018. Sustainable chemical processing and energy-carbon dioxide management: Review of challenges and opportunities. Chemical Engineering Research and Design 131, 440-464. doi:10.1016/j.cherd.2017.12.019

Wang, Z., Krupnick, A., 2015. A Retrospective Review of Shale Gas Development in the United States: 
What Led to the Boom? Economics of Energy \& Environmental Policy 4 (1). doi:10.5547/21605890.4.1.zwan

Wei, J., Russel, T.W.F., Swartzlander, M.W., 1979. The structure of the chemical processing industries: function and economics. McGraw-Hill, New York.

Wismann, S.T., Engbæk, J.S., Vendelbo, S.B., Bendixen, F.B., Eriksen, W.L., Aasberg-Petersen, K., Frandsen, C., Chorkendorff, I., Mortensen, P.M., 2019. Electrified methane reforming: A compact approach to greener industrial hydrogen production. Science 364, 756-759. doi:10.1126/science.aaw8775

Woodley, J.M., 2019. Accelerating the implementation of biocatalysis in industry. Applied Microbiology and Biotechnology 103, 4733-4739. doi: 10.1007/s00253-019-09796-x.

You, F., Tao, L., Graziano, D.J., Snyder, S.W., 2012. Optimal design of sustainable cellulosic biofuel supply chains: Multiobjective optimization coupled with life cycle assessment and input-output analysis. AIChE Journal 58, 1157-1180. doi:10.1002/aic.12637

Zhang, L., Babi, D.K., Gani, R., 2016. New Vistas in Chemical Product and Process Design. Annual Review of Chemical and Biomolecular Engineering 7, 557-582. doi:10.1146/annurev-chembioeng080615-034439

Zhang, L., Fung, K.Y., Wibowo, C., Gani, R., 2018. Advances in chemical product design. Reviews in Chemical Engineering 34, 319-340. doi:10.1515/revce-2016-0067

Wu J., Prausnitz, J. M., 2019., $110^{\text {th }}$ Anniversary: Molecular Thermodynamics - An Endless Frontier IECR, 58, 9707-9708 


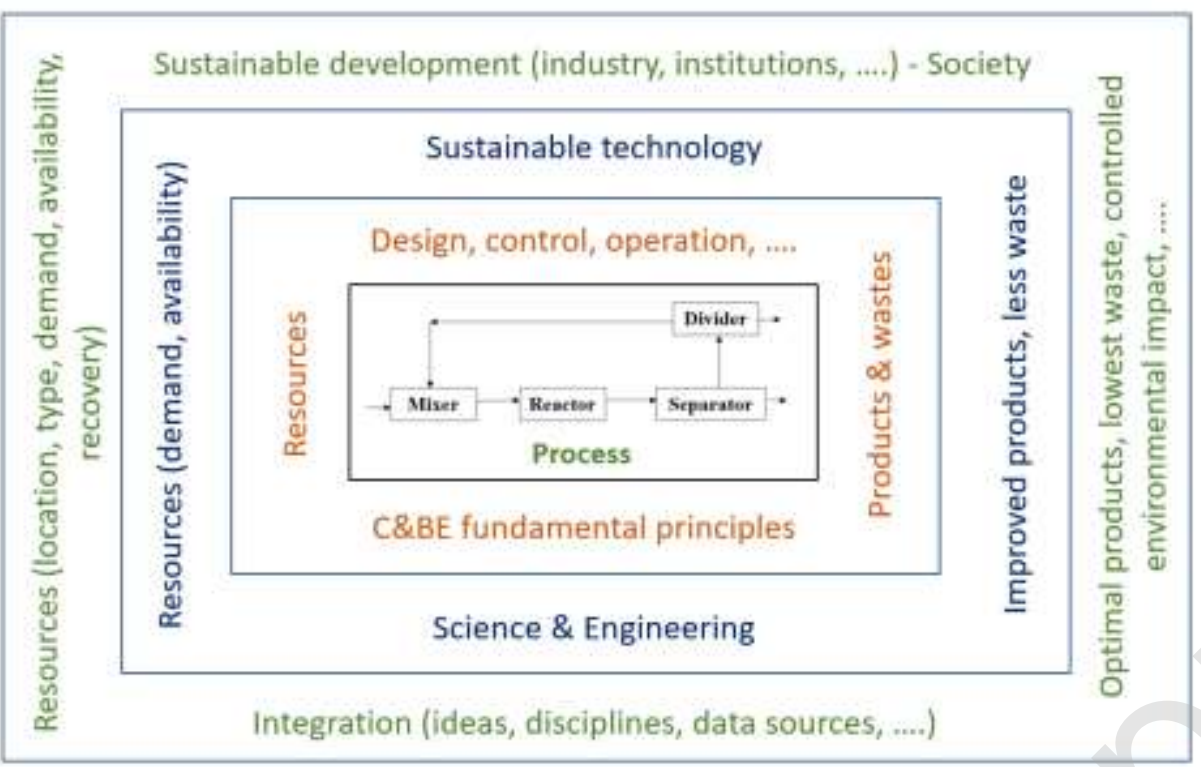

Figure 1: The multi-layered view of chemical and biochemical engineering (note: increasing details of the same resources (raw materials and utilities such as energy and water) are considered, moving from inner to outer layers).

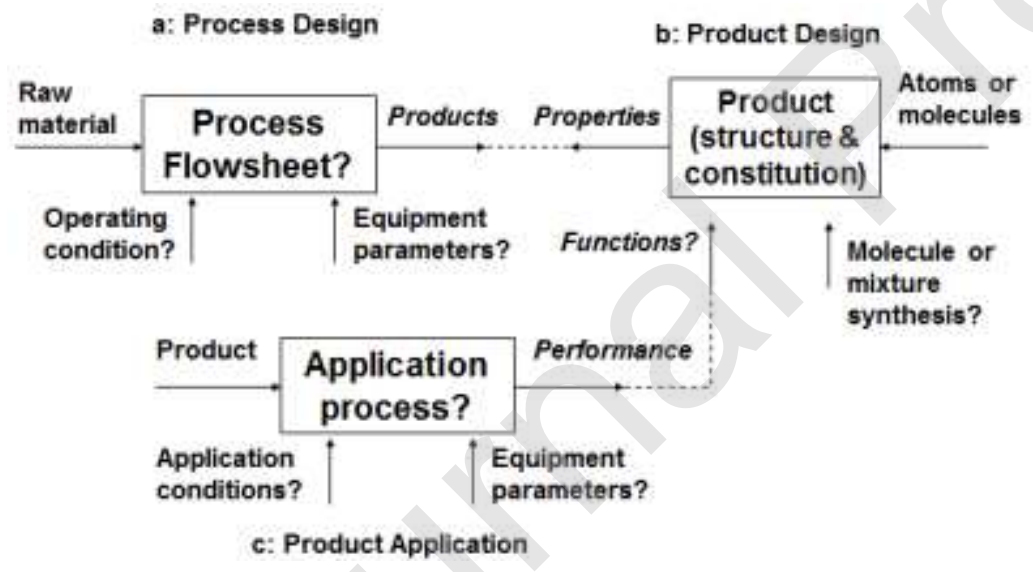

Figure 2: Relationships between product-process design and product design-product application. The dashed lines indicate the link between the design and application problems (Zhang et al., 2016). 


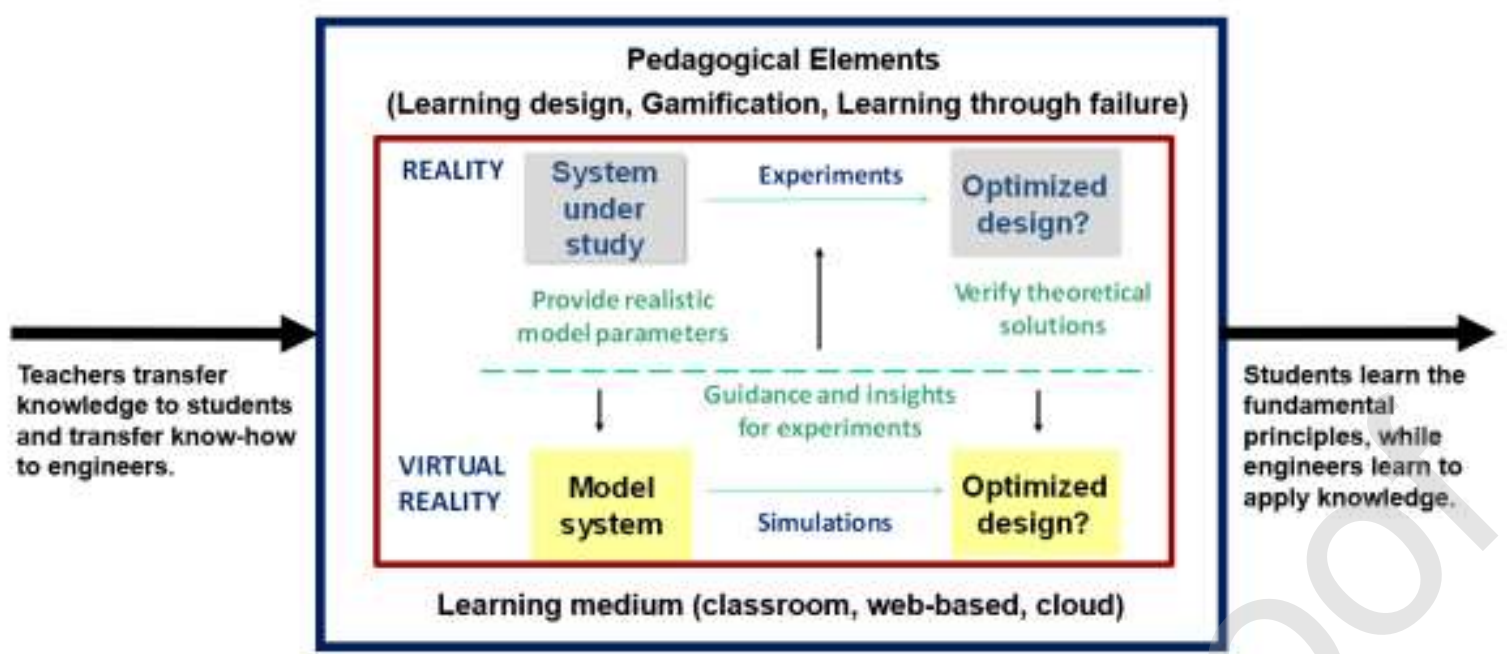

Figure 3: The drivers for developing a virtual laboratory

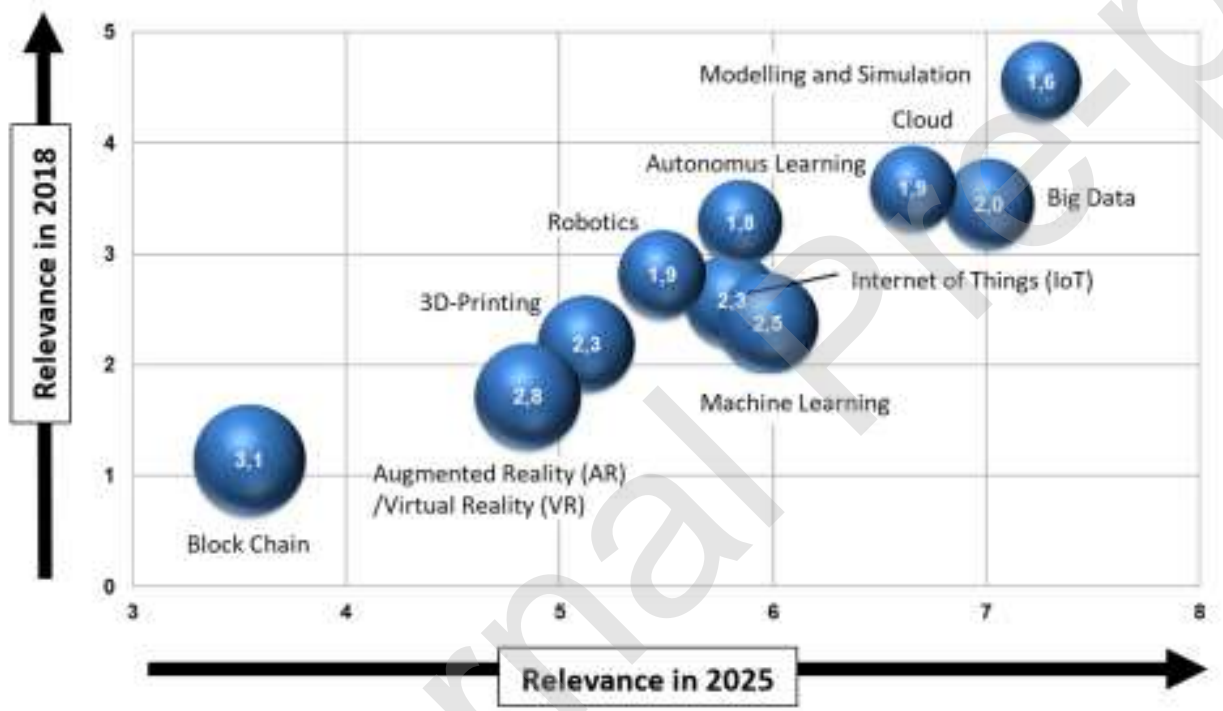

Figure 4: Industry 4.0 relevance in the next 10 years (Keller, 2018) 


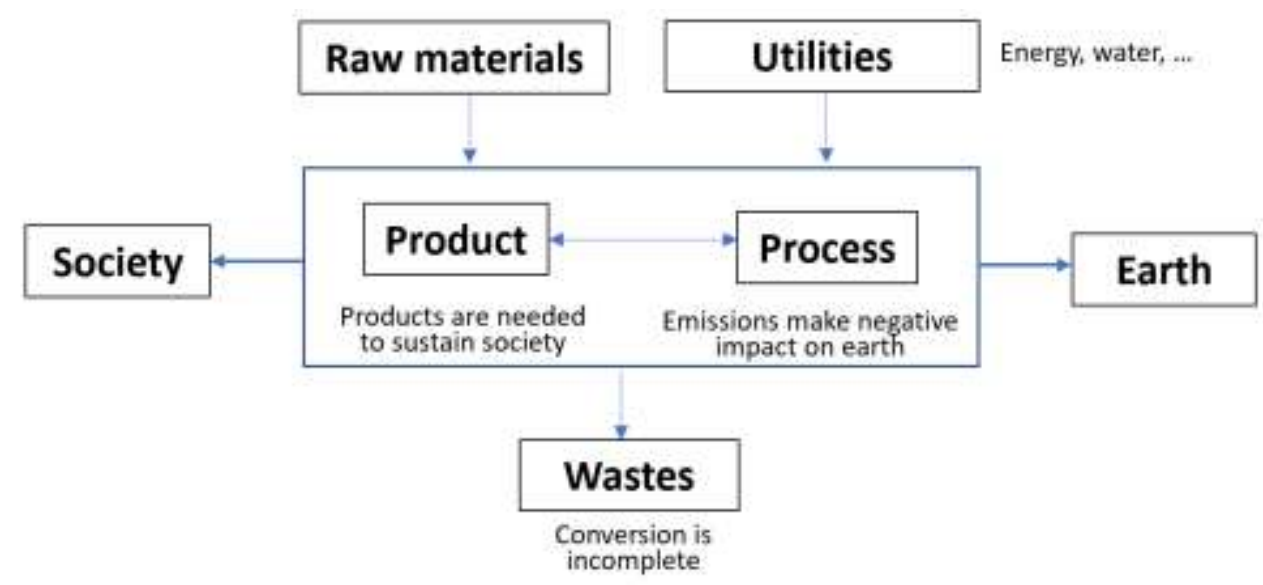

Figure 5: Use of resources by C\&BE 
Table 1: Forms of industrial practice and their activities

\begin{tabular}{|l|l|l|lr|}
\hline $\begin{array}{l}\text { Practice form (type of } \\
\text { company) }\end{array}$ & What they do or use & $\begin{array}{l}\text { What they need or } \\
\text { consume }\end{array}$ & $\begin{array}{l}\text { What they give to } \\
\text { society or results }\end{array}$ \\
\hline Manufacturing & $\begin{array}{l}\text { Apply production } \\
\text { technologies }\end{array}$ & $\begin{array}{l}\text { Resources (material, } \\
\text { utility, human-power) }\end{array}$ & $\begin{array}{l}\text { Manufactured products } \\
\text { that society needs }\end{array}$ \\
\hline Engineering & $\begin{array}{l}\text { Use technics, methods, } \\
\text { data }\end{array}$ & $\begin{array}{l}\text { Resources (human- } \\
\text { power) }\end{array}$ & $\begin{array}{l}\text { Production for } \\
\text { technologies for } \\
\text { manufacturing }\end{array}$ \\
\hline Equipment & $\begin{array}{l}\text { Design-develop } \\
\text { production equipment }\end{array}$ & $\begin{array}{l}\text { Resources (material, } \\
\text { utility, human-power) }\end{array}$ & $\begin{array}{l}\text { Equipment } \\
\text { manufacturing industry }\end{array}$ \\
\hline Software & $\begin{array}{l}\text { Develop knowledge } \\
\text { theory, concepts) } \\
\text { based tools }\end{array}$ & $\begin{array}{l}\text { Resources (human- } \\
\text { power) }\end{array}$ & $\begin{array}{l}\text { Tools } \\
\text { implemented methods } \\
\text { and data }\end{array}$ \\
\hline Consulting & $\begin{array}{l}\text { Solve problems using } \\
\text { the needed data, } \\
\text { methods \& tools to help } \\
\text { apply-develop } \\
\text { technologies }\end{array}$ & $\begin{array}{l}\text { Resources (human- } \\
\text { power), knowledge } \\
\text { theory, concepts, data) }\end{array}$ & $\begin{array}{l}\text { Problem solutions } \\
\text { (technology, methods, } \\
\text { tools) }\end{array}$ \\
\hline
\end{tabular}


Table 2: Types of chemicals-based products and their characteristics (adapted from Cussler \& Moggridge, 2001)

\begin{tabular}{|l|l|l|l|}
\hline \multirow{2}{*}{ Characteristics } & Product types \\
\cline { 2 - 4 } & Commodity-based & Molecule-based & Microstructure-based \\
\hline Key issue & Cost & Speed & Function \\
\hline Basis for success & Unit operations & Chemistry & Microstructure \\
\hline Risk of failure & Feedstock & Discovery & Science \\
\hline
\end{tabular}

